\title{
Need Of Interfaith Dialogue For Peace Building In Pakistan: An Approach Of Madrasa Teachers In South Punjab
}

\author{
Mansoor Ali Shah \\ \& \\ Asif Naveed Ranjha \\ Department of Social Work \\ The Islamia University of Bahawalpur
}

\begin{abstract}
Dialogue among religions, as growing social need and tool for peace building, is coming on international limelight as response to intolerance and conflict. The phenomenon of interfaith dialogue is popularly carried out by sacred and religious leaders of varying faiths as being the most relevant stakeholders. This research was undertaken to explore the perspective of madrasa teachers about the need of interfaith dialogue in Pakistan. Male teachers of registered ahle-sunnat madaris in south Punjab constituted the population of the research study. 325 respondents were included in study by employing availability sampling technique. Five-point likert scale questionnaire was used to collect data. It was found from the results that teachers of madaris did not perceive interfaith dialogue as only step towards promotion of peace. Absence of interfaith dialogue has nothing to do with the phenomenon of terrorism, came up as opinion of madrasa teachers but in contrast some teachers took interfaith dialogue as helpful tool to control the peril of terrorism. Study also revealed that large number of madrasa teachers favored interfaith dialogue as instrumental to reduce the risk of conflict among various religious entities. Results also indicate that madrasa faculty considered interfaith dialogue needed to learn tolerance for counter beliefs. However many of the faculty members of madaris disowned the conduct of interfaith dialogue as their social responsibility.
\end{abstract}

Keywords: Interfaith Dialogue, Madrasa, Peace, Ahle-Sunnat.

$$
\begin{aligned}
& \text { تخاخص }
\end{aligned}
$$

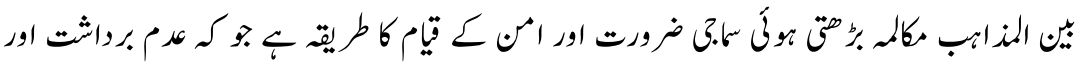

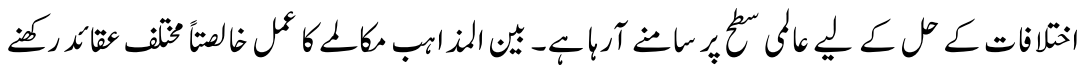

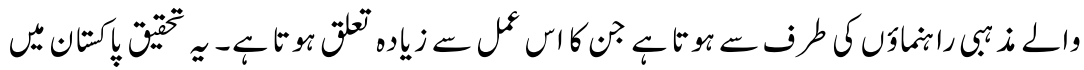

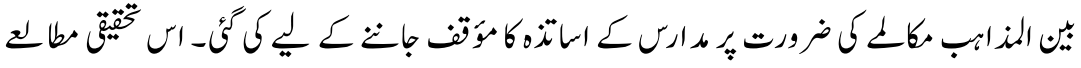




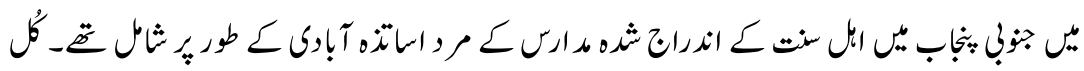

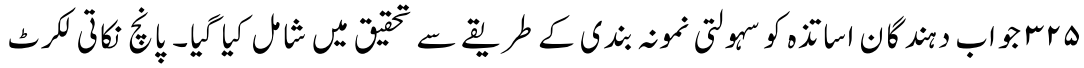

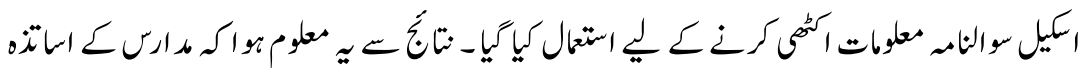

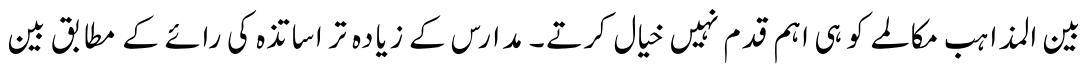

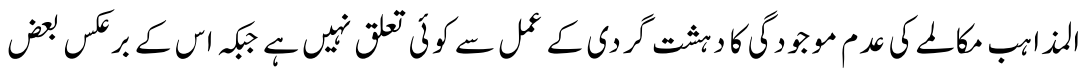

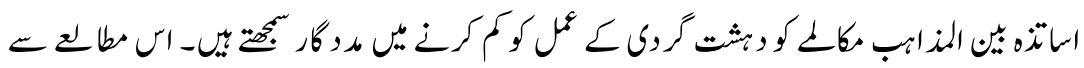

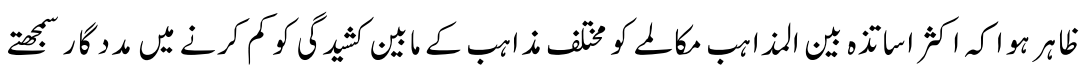

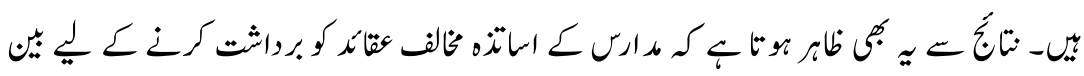

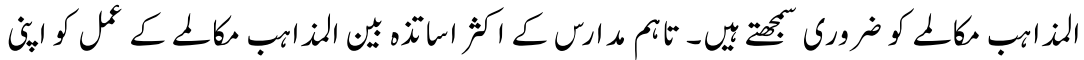

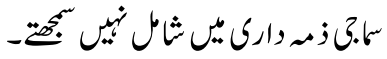

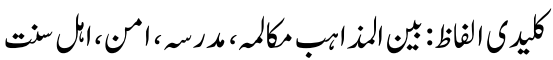

\section{Introduction}

Peace and peace building have become the most serious and conspicuous concern of the present day world. Efforts around the globe are going on to establish peace whereby apart, from other options for peace building interfaith dialogue has come to limelight and has caught the attention of stake holders. Peace is taken as complex and continuous process due to its changing nature and need which are linked with human survival. Political and religious aspects are valued in peace as it is mainly concerned with human wellbeing being (Carr, 2014). Quoting Oscar Romero, Sahin (2009) mentions peace as generosity, right, duty and dynamism.

Peace is absence of war or violence. It must also be coupled with prompt justice because peace devoid of justice is no peace. In each time and clime peace has been a dire human need but in this modern age peace has become that much imperative for the society that survival of humankind now rests on it. It has now become the matter of life and death for human kind. That's why peace with presence is life and peace with absence is death (Khan, 2015). Dialogue implies to purposeful and meaningful talk among the people with different identities and backgrounds to come closer and to develop a deeper understanding about each other (Kurucan \& Erol, 2012). Peace is the primary right of every human being dwelling beneath the sky and for peace non-violence stands as a prerequisite. Humans are made to live non-violently and by doing so peace could be established (Kefa \& Moses, 2012). 
Interfaith dialogue is a productive interaction of the people who are the devotees of different religions with different dogmatic patterns, with the resolution to reach at cohesions in faith and value structure to find the potentials for peaceful and nonviolent co-existence (Sanaullah, 2014). Interfaith dialogue designates to convergence of souls amongst the adherents of opposing religions. It refers to fruitful discussion between followers at religious level. It's a communal walk on the road to truth and enterprise in projects of shared interests (Arinze, 1990). Mahmood and Ghauri (2013) argue that globalization period is high time of interfaith dialogue to understand others. Interfaith dialogue is essential instrument to terminate conflicts and to build peace (Farjan, 2013). We witness another argument by Salwa Kader that interfaith dialogue can be taken as tool for developing understanding between people having different faiths (Mehta, 2016). She further explains that religion cannot be blamed for violence which is considered by some circles. Religious differences have always been one of the conspicuous landscapes of human society. This is why interfaith dialogue has been existent in one or other form from the olden days. Prophet Muhammad (PBUH) nearly fourteen hundred years before arranged a three-religion conference that we call a trilogue to discuss and share understanding on religious affairs. The objective of dialogue should always be to arrive at settlement on applied aspects instead of theoretical aspects of religion. Interaction of the people belonging to different faiths is an un-proclaimed dialogue in itself that serves the purpose of dialogue on its own (Khan, 2015).

The institute in which schooling about Islam is rendered is called Madrasa. This word comes from Arabic language. Madrasa imparts education in Quran, Hadith, Fiqh alongside science, literature, logic and languages. They also train the students on Islamic life style (R. Ahmed, Dahar, \& Dahar, 2016).

According to Bano (2007a) madrasa education system was playing vital role in free education of more than 1.5 million children as state had shortage of institutions and quality education. Bano (2007b) finds different system and order of knowledge in madrasa in Pakistan where knowledge evaluation is based on well designed mechanism. In Pakistan, South Punjab is the house of a large number of madaris which also contain a large number of students and faculty. Wafaq-ul-Madaris-ul-Arabiya Pakistan represents Deoband school of thought, Tanzeem-ul-Madaris-ul-Arabiya represents Barelvischool of thoughts and Wafaqul-Madaris-ul-Salfia represents Ahle Hadith school of thought (M. R. Ahmad, 2013). Pakistan is the country where mainstream of the people are traditional and are tending towards religion. This robust attachment with religion always favored for rendering religious education. That's why madaris (seminaries), imparting services of religious and spiritual education, are found every wherein the country. 
This research work is based on MPhil dissertation. It is characterized with the objective to study the perspective of madrasa teachers regarding need of interfaith dialogue. Teachers of madaris, situated in south Punjab, were respondents of the study. This research work helped to know what were madrasa people thinking regarding interfaith dialogue as a growing social need and step towards establishing peace. Questions pertaining to need of dialogue in Pakistan and role of madrasa faculty were included.

\section{Literature Review}

The term interfaith dialogue that has numerous implications first came into use in western nations almost three decades before and later it routed to other parts of the world. To resuscitate the relations with the entire world interfaith dialogue is incumbent for Islam. Holy Quran also calls for dialogue on mutual terms with the people of Book (Nadvi, 2012).

Predominantly interfaith dialogue is a process of verbal discussion grounded on words of understanding and respect. It is a bilateral process in which two or more parties endeavor to display what they believe in and listen others with respect. Its objective is to learn truth from one another. It also encourages thinking out of box by breaching shells around to explore more truth. This is only dialogue through which we may enrich our understanding and can curtail the abhorrence and incorrect perceptions about fellow humans (Khambali, Sintang, Senin, \& Shahrud-Din, 2013).

Dialogue among religions can be supportive in elevating our understanding about ourselves by contextualizing with others who have difference of faith tradition than that of ours (Kurucan \& Erol, 2012). Inter-religious dialogue will assist to avert the misapplication of religion for vested interest. In the present day world different political, economic and geo-political conflicts amongst states are termed as conflicts among religions. De-politicization of religion is necessary for the present world and could only be done through a thoughtful and meaningful dialogue (A. Ali, 2012). According to Scheffler (2007) peace is not there among religions if dialogue does not exist among religions.

Interfaith dialogue is not an answer to all the worries of the world especially where there is long-standing chaos and political shakiness. When there is dire unevenness of control and deficiency of political will, there dialogue fails to work. There is no victor and loser in dialogue its lone objective is to land on certain viable settlement. It further endeavors to bring the people nearer and makes them share their standpoints and discover novel designs. Dialogue does not work instantaneous to settle the matters rather it has to go a long way to drag the tension to an end and to pave the way towards economic and social prosperity 
(UNDP, 2009). Interfaith dialogue must be undertaken with unambiguous and evidently explained objectives. Through dialogue mutual problems like problems of community living, women specific issues, leadership matters etc. should be conversed to work out some broadly and collectively agreed solutions. Interfaith dialogue occurs when adherents of different religions come closer with the intention to enhance understanding about one another. Dialogue is a way forward to solve numerous long lived problems and misconstructions. Dialogue is never evangelism and debates rather an attempt to comprehend and appreciate those who are dogmatically different from you (Yusof \& Ab Majid, 2012).

According to Joyner and Mengistus (2012), top leadership is not preferred to undertake the process of interfaith dialogue. For this purpose, local level leadership is more preferred which has additional potential to establish peace by making people engaged in dialogue. Interreligious dialogue does not target to transform or to get part-taker into complete agreement to devise a novel religion that is commonly acceptable. Rather it resolves to achieve a compassionate understanding of others so that existing with peace and coherence may come true. It further resolves to uphold spirit of trust and to get people work together for social advancement (Castro, 2006).

Nadvi (2012) argues that keeping the path and pace desirable, dialogue should not be altered into a fiery debate because debate will not attain anticipated goals and will contribute in dissonance and will yield vehemence pushing peace far-flung. For having interfaith dialogue on right course, dialogue must be carried out only by those who are with vast knowledge and acumen and have grasp on religious matters. Politicians are never supposed to be the part of interfaith dialogue. Objectives must be set with agreement of all stakeholders who take part in dialogue. To arrive at worthy results all partakers of dialogue should admit the importance and value of each other. This type of dialogue can harvest the consequences of prevailing worldwide peace, resolution of conflicts and can ensure the promotion of education, justice and economic security for all (Jami, 2012). As dialogue is a scholarly discourse so it has to be only by those who enjoy proficiency in religious matters (Yusof \& Ab Majid, 2012). Villumstad (2002) accentuated that principle of fair representation is extremely essential to be esteemed. Only contemporaries and compatibles can participate in dialogue process. Disparity of stature like master and slave, affluent and pauper, erudite and uneducated controverts the spirit of dialogue. Talks must be arranged within a meta-religious outline which evolves a reception to the communal dogmas of parties without any prejudices to the dissimilarities. Furthermore, do not conceal your thoughts rather be open about dissimilarities without making any degradation and criticism. It is also in line with principle that never compels others to get transformed over your side (I.-a.-D. Ahmad, 2008). 
In principle religious specialists and leaders are the most appropriate ones who can take forward the phenomenon of interfaith dialogue for establishing peace. Failure in doing so would never produce the anticipated outcomes of dialogue (Karim, Saili, \& Khambali, 2014). Since centuries religion has always been a cause of encounter and polarity amongst societies having different religious and cultural identities. Where the admirers of varying religions and belief systems plunge in conflicts, there religious and irreligious groups also collide with each other. That's why in dialogue process taking both religious and nonreligious actors onboard is vital. For the establishment of peace, part of religious scholars and authorities and religious institutions has to be stretched (Rasul, 2009).

West has twofold face as on one side there is invitation for interfaith dialogue whereas on the other side the doctrine of clash of civilization is getting stronger acceptability in the minds of westerns. As a matter of fact west is striving to overthrow all opposing civilizations through the smokescreen of interfaith dialogue otherwise they have nothing to do with counter faiths (Hayat, 2012). According to Koreshi (2001), dialogue among the unlike faith groups has no importance in present world any more. World is speedily slipping towards a ferocious and gory clash among religions and civilizations. At smaller level this clash is very apparent between Islam and Hinduism and Christians and on larger level we can anticipate it between the west and the rest (Huntington, 1997). There are uninterrupted attempts to make Muslim world militarily feeble and reliant on economic super powers (Joyner \& Mengistus, 2012).

To counter the doctrine of Clash of Civilizations by Huntington, dialogue is obligatory for keeping world in order instead of fashioning a new world order. Hans Kung rightly says "No world order without peace; no peace in the world without dialogue between the world religions; no world order without a global ethic. No efficacious global ethic without a genuine dialogue between the world of religions" (Coleman, 2007).

Madrasa, as a word of Arabic language that means of 'centre of learning' (Z. S. Ahmed, 2009). It also denotes to a school of religious and spiritual education (M. M. Ali \& Kishore, 2014). Madrasa stands for a conventional and conservative school for teaching Islam as religion with the major goal to produce a lot of Islamic scholars and intellectuals to guide and lead Muslim Ummah (H. Ali, Mashhadi, \& Khan, 2015).

In Pakistan, some madaris are merely offering services related to oration skills of Holy Quran however; most of the madaris are offering Dars-e-Nizami, an eight year course in religious sciences. Each madrasa is registered with one or other education board identified as Wafaq (education board). Total four Wafaqs are 
operating in Pakistan representing different school of thoughts. Out of four, three Wafaqs represent three different Sunni schools of thoughts whereas one Wafaq represents Shia school of thought (M. R. Ahmad, 2013).

The time Pakistan came into reality in 1947 there were nearly 137 madaris operating in Pakistan but in forthcoming years this number swiftly increased to 20000 (Abu-Nimer \& Kadayifci, 2011). In 1960 this figure increased to 401, in 1971 it reached to 893, during 1979 this number elevated to 1745 and in 1988 the count of madaris reached to 3000. Currently there are almost 35,000 madaris operating in Pakistan out of which only Punjab is housing nearly 12000 madaris. The unregistered and unfettered madaris in Fata are other than these (Ramzan, 2015). It is a compelling reality that madaris are serving society by giving free education with boarding facility to a large number of students (M. R. Ahmad, 2013).

In Pakistan total four Wafaqs (Boards) are functioning which represent different school of thoughts. Three Wafaqs represent three different Sunni schools of thoughts whereas one Wafaq represents Shia school of thought. Wafaq-ulMadaris-ul-Arabiya Pakistan, established in 1959, represents Deoband school of thought with head office in Multan, Tanzeem-ul-Madaris-al-Arabiya, established in 1960, represents Barelvi school of thought with head office in Karachi and Wafaqul-ul-Madaris-al-Salfia, established in 1955, represents Ahle Hadith school of thought with head office in Faisalabad (M. R. Ahmad, 2013). All the Wafaq (Boards) are responsible to register and give accreditation to madaris of their corresponding sect, design curriculum, arrange examinations and do certification. In Pakistan madaris are thought to be welfare-oriented organizations which render not only free education but also offer the facility of boarding and accommodation to indigent students (Ramzan, 2015).

Sect-wise breakup explained that Barelvi madaris are 6606 in figure followed by Deobandimadaris which are 6106 around the Punjab province. The figure of registered Barelvi madaris are 3656 and rest of the 2950 are unregistered. Likewise, 3092 Deobandi madaris are registered and 3014 madaris are unregistered in Punjab. Whereas, Ahl-e-Hadith have 840 madaris with 408 as registered and 432 madaris as unregistered (The Express Tribune, 2015). Southern Punjab is housed with plethora of madaris which cater great number of students and faculty members (M. R. Ahmad, 2013). The aggregate figure of madaris belonging, to these three schools of thoughts are 4660 in three divisions (Bahawalpur, Multan and Dera Ghazi Khan) of South Punjab, with the division of 
2298 madaris of Barelvi sect , 2158 madaris of Deoband sect and 204 madaris of Ahl-e-Hadith sect (Ramzan, 2015).

\section{Methodology}

The present study is descriptive in nature and was under taken by employing social survey method. To collect the data, Five-Point Likert-type scale questionnaire was devised and administered. Teachers of registered madaris of AhleSunnat school of thought were the population of the study. The geographical area of the study was three divisions (Multan, Bahawalpur and Dera Gazi Khan) of South Punjab. Quota sampling method coupled with availability sampling method was opted as sampling technique to draw desired sample. Data collection process took a period of three month as all the respondents were physically approached. As the respondents were not conversant with English language the tool of data collection was translated into Urdu language. After the accomplishment of data collection, data was analyzed by Statistical Package for Social Sciences (SPSS) to reach at results and conclusion. To delimit the study, limitations were set whereby faculty members of only south Punjab madaris, faculty members who only teach students of Dars-e-Nizami, only male faculty members and faculty of Ahl-e-Sunnat madaris were included in study.

\section{Results and Discussion}

Table: 1

Only interfaith dialogue will ensure peace in Pakistan

\begin{tabular}{|l|c|c|}
\hline Response & Frequency & Percentage \\
\hline Agree & 58 & 17.8 \\
\hline Strongly Agree & 30 & 9.2 \\
\hline Don't Know & 15 & 4.6 \\
\hline Disagree & 202 & 62.2 \\
\hline Strongly disagree & 20 & 6.1 \\
\hline Total & 325 & 100 \\
\hline
\end{tabular}

Above table is about the results pertaining to peace in Pakistan through interfaith dialogue. $62.2 \%$ respondents disagreed that interfaith dialogue was only way towards peace in Pakistan and 6.1\% respondents strongly disagreed that interfaith dialogue would ensure peace in Pakistan. Nearly one fifth (17.8\%) respondents agreed with interfaith dialogue as only step towards peace. $9.2 \%$ respondents strongly agreed with the statement whereas, $4.6 \%$ respondents expressed indifference about it. 
Table: 2

Interfaith dialogue will help to understand and respect each other religion

\begin{tabular}{|l|c|c|}
\hline Response & Frequency & Percentage \\
\hline Agree & 116 & 35.7 \\
\hline Strongly Agree & 37 & 11.4 \\
\hline Disagree & 93 & 28.6 \\
\hline Strongly disagree & 79 & 24.3 \\
\hline Total & 325 & 100 \\
\hline
\end{tabular}

Table 2 contains results about understanding and respecting each other religion through dialogue. Almost one third (35.7\%) respondents agreed that dialogue would help to understand and respect the religion of other people. Some respondents (11.4\%) expressed strong agreement with the statement. Over one fourth $(28.6 \%)$ respondents went in disagreement with it whereas; another one fourth $(24.3 \%)$ respondents exhibited strong disagreement and opposed the statement.

Table: 3

Present wave of terrorism in Pakistan is due to absence of effective interfaith dialogue

\begin{tabular}{|l|c|c|}
\hline Response & Frequency & Percentage \\
\hline Agree & 55 & 16.9 \\
\hline Strongly Agree & 12 & 3.7 \\
\hline Disagree & 182 & 56 \\
\hline Strongly disagree & 76 & 23.4 \\
\hline Total & 325 & 100 \\
\hline
\end{tabular}

The above drawn table goes to exhibit findings about present wave of terrorism and absence of interfaith dialogue. A large number of respondents $(56 \%)$ opined that wave of terrorism was not due to absence of interfaith dialogue, $23.4 \%$ respondents also disagreed with the statement with strong voices. However, some respondents (16.9\%) agreed that present wave of terrorism was due to absence of interfaith dialogue and $3.7 \%$ emphasized the statement in agreement.

Table: 4

Interfaith dialogue will help to control the menace of terrorism

\begin{tabular}{|l|c|c|}
\hline Response & Frequency & Percentage \\
\hline Agree & 133 & 40.9 \\
\hline Strongly Agree & 97 & 29.8 \\
\hline Disagree & 70 & 21.5 \\
\hline Strongly disagree & 25 & 7.7 \\
\hline Total & 325 & 100 \\
\hline
\end{tabular}

The above drawn table holds the results in regard to control the menace of terrorism through interfaith dialogue. More than one third respondents $(40.9 \%)$ 
expressed moderate agreement with the statement while $29.84 \%$ respondents expressed strong agreement. Almost one fifth respondents $(21.5 \%)$ disagreed that interfaith dialogue would help to control the menace of terrorism whereas; some respondents $(7.7 \%)$ strongly disagreed with the statement. Majority stood in agreement with the said phenomenon.

Table: 5

Interfaith dialogue will reduce the risk of conflicts among various religious entities in Pakistan

\begin{tabular}{|l|c|c|}
\hline Response & Frequency & Percentage \\
\hline Agree & 211 & 64.9 \\
\hline Strongly Agree & 68 & 20.9 \\
\hline Don't Know & 3 & 0.9 \\
\hline Disagree & 32 & 9.8 \\
\hline Strongly disagree & 11 & 3.4 \\
\hline Total & 325 & 100 \\
\hline
\end{tabular}

This table speaks about the results regarding reduction of risk of conflicts among various religious entities in Pakistan through interfaith dialogue. A dominant number of respondents $(64.9 \%)$ went in moderate agreement that interfaith dialogue would reduce the risk of conflicts among various religious entities whereas, $20.9 \%$ respondents showed a strong agreement in favour of the statement Some respondents $(9.8 \%)$ were disagree whereas, 3.4\% respondents expressed strong disagreement.

Table: 6

Interfaith dialogue will help to learn tolerance for counter beliefs

\begin{tabular}{|l|l|l|}
\hline Response & Frequency & Percentage \\
\hline Agree & 157 & 48.3 \\
\hline Strongly Agree & 83 & 25.5 \\
\hline Don't Know & 13 & 4 \\
\hline Disagree & 42 & 12.9 \\
\hline Strongly disagree & 30 & 9.2 \\
\hline Total & 325 & 100 \\
\hline
\end{tabular}

The above table shows findings related to learning tolerance for counter beliefs through interfaith dialogue. Almost one half respondents (48.3\%) respondents favored that dialogue would help to learn tolerance for counter beliefs. Whereas, $25.5 \%$ respondents were in strong favor with the statement. Some respondents $(12.9 \%)$ agreed and other $9.2 \%$ respondents strongly disagreed with it. 
Table: 7

Teachers of madaris should take part in interfaith dialogue as their social responsibility

\begin{tabular}{|l|l|l|}
\hline Response & Frequency & Percentage \\
\hline Agree & 45 & 13.8 \\
\hline Strongly Agree & 18 & 5.5 \\
\hline Disagree & 227 & 69.8 \\
\hline Strongly disagree & 35 & 10.8 \\
\hline Total & 325 & 100 \\
\hline
\end{tabular}

Table 7 goes to explain results about teachers of madaris should take part in interfaith dialogue as their social responsibility. Majority of the respondents (69.8\%) disagreed and opined that teachers of madaris should not take part in interfaith dialogue.10.8\% respondents strongly disfavored the statement. In contrast $13.8 \%$ respondents were in favor of taking part in dialogue process as their responsibility. While a small number of respondents $(5.5 \%)$ stood in strong favor with the statement.

Mehta (2016) takes interfaith dialogue as a way for promoting understanding between people who belong from different beliefs. The majority of madrasa teacher respondents do not take interfaith dialogue as only way forward for establishing peace across country. This finding seems very close the discussion made by Krebs (2014) that considering only religion for dialogues to build peace can put blames for violence on religion. It can be witnessed from results of the study that the opinion of respondents is almost equally divided in favor and against on interfaith dialogue as an attempt to build an understanding for each other religion. This depicts that madrasa people somehow agree with the constructive effect of dialogue among religions. However, they go on to believe that only interfaith dialogue has not major role in mitigating terrorism from society. Present wave of terrorism in our society has nothing to do with the absence of interfaith dialogue. According to Mehta (2016), Kader also negates connection of violence with religion. Violence or terrorism could be is more connected with injustice, poverty and abandoning religious teachings. Yes, interfaith dialogue could be helpful to reduce the threats of conflicts and violence. Majority of respondents agree that dialogue can be helpful to respect other and to understand other religions. This seems an agreement to Khambali et al. (2013) that interfaith dialogue is a discussion leading towards understanding about others and their respect.

More than half respondents do not consider absence of interfaith dialogue as reason behind terrorism in Pakistan. While, nearly one fifth argue that absence of dialogue is main cause for terrorism. Old (2016) has also similar opinion that only interfaith dialogues cannot stop terrorism but he further argues in favour of 
dialogue as helpful tool for giving realistic responses when terrorism does happen. On the other hand majority of madrasa teachers considers interfaith dialogue helpful to control menace of terrorism. To them solution lies in addressing long standing social problems and needs of people. In contrary to this faculty from madaris think that risk for conflict among different religious entities in Pakistan may be reduced through dialogue and expression of disregard and disrespect could be prevented. Scheffler (2007) argues the same that non existence of interfaith dialogue is indication of no peace among different religions. Moreover, environment of tolerance can be cultivated for people of counter belief. This is where they favour dialogue process to get some positive results. It was found that faculty of madaris don't consider themselves right person to get engaged in dialogue process rather renowned scholars with deeper understanding of comparative studies should get into this process to gain desired results.

\section{Conclusions}

The findings of the study came up with the conclusion that majority of faculty members of madaris did not take interfaith dialogue as the only recipe to establish peace in Pakistan but teachers of madaris were largely favoring interfaith dialogue as tool to develop a sense of understanding and respect for each other faiths. The results of the study also depicted that present wave of terrorism in Pakistan was not because of the absence of effective interfaith dialogue process as dominant number of teachers in madaris did not link terrorism with absence of interfaith dialogue but in contrast majority of respondents acknowledged that interfaith dialogue would somehow help to reduce the menace of terrorism. The findings of the study also indicated that interfaith dialogue would be instrumental to reduce the risk of conflicts and tensions among divergent religious entities. It is also the part of conclusion that overwhelming majority of teachers of madaris considered interfaith dialogue as helpful to learn tolerance for counter beliefs. It was finally derived from the study findings that dominant majority of madrasa teachers took interfaith dialogue as non-responsibility on their credit. The findings of the study suggest that faculty of madaris should get interfaith-dialogue studies included in their curriculum as permanent part. It also depicts the need of state sponsored version of dialogue to develop uniformity for all stake holders.

\section{References}

Abu-Nimer, M., \& Kadayifci, A. (2011). Human rights and building peace: the case of Pakistani madrasas. The International Journal of Human Rights, 15(7), 1136-1159.

Ahmad, I.-a.-D. (2008). Reflections on Inter/Intra-faith Dialog and Promotion of World Peace in the Light of Muslim Heritage. Paper presented at the 37th 
Annual Conference of the Association of Muslim Social Scientists of North America (AMSS) "Crossing Boundaries: Mobilizing Faith, Diversity and Dialogue”, Harvard Divinity School, Harvard University Cambridge, MA.

Ahmad, M. R. (2013). Entrepreneurial Attitude Among Madrassa Students In Pakistan. MPhil, The Islamia University of Bahawalpur.

Ahmed, R., Dahar, R. T., \& Dahar, M. A. (2016). Tradition and Modernity of Madrassah Teachers: Academic and Professional Qualification, Teachers Training and Salaery in Punjab (Pakistan). Science International (Lahore), vol.28:2, pp.2079-2083.

Ahmed, Z. S. (2009). Madrasa Education in the Pakistani Context: Challenges, Reforms and Future Directions. Peace Prints: South Asian Journal of Peace building, vol.2:1, pp.1-13.

Ali, A. (2012). On interfaith dialogue, Dawn. Retrieved from https://www.dawn.com/ news/699551

Ali, H., Mashhadi, A. F., \& Khan, E. A. (2015). Role of Madrassa Education in Present Globalized Society: Perspectives of Religious Teachers of Southern Punjab. Pakistan Journal of Social Sciences (PJSS), vol.35:2, pp.609-618.

Ali, M. M., \& Kishore, D. K. (2014). Secular Attitude: a Study of Madrasa Students. Indian Journal of Applied Research, vol.4:11, pp.167-169.

Arinze, F. C. (1990). The Church in Dialogue: Walking With Other Believers. USA: Ignatius Pr.

Bano, M. (2007a). Beyond politics: The reality of a Deobandi madrasa in Pakistan. Journal of Islamic Studies, vol.18:1, pp.43-68.

Bano, M. (2007b). Contesting ideologies and struggle for authority: State-madrasa engagement in Pakistan. Birmingham: International Development Department, University of Birmingham.

Carr, F. (2014). Peace-building through Ecumenical and Interfaith Dialogue. Retrieved from https://scholar.google.com.pk/scholar?hl=en\&as_sdt $=0 \%$ 2C5\&q=Peace-building+through+Ecumenical+and+Interfaith+Dialogue + Felicita + Carr\&btnG $=$ 
Castro, L. N. (2006). The Role of Education in Promoting Interfaith Cooperation. Paper presented at the Dialogue on Regional Interfaith Cooperation for Peace and Human Dignity, Cebu.

Coleman, J. A. (2007). Inter-Religious Dialogue: Urgent Challenge and Theological Land-Mine. Paper presented at the The Slattery Lecture, at the University of Notre Dame Australia, Australia.

Farjan, A. Y. (2013). Perception of Interafith Dialogue in Pakistan: A Study of the Past Twenty Years. Masters, International Islamic University, Islamabad.

Hayat, U. (2012). Contemporary Clash of Civilization and Interfaith Dialogue. Paper Presented at the International Seerat Conference, The Islamia University of Bahawalpur.

Huntington, S. P. (1997). The Clash of Civilizations and the Remaking of World Order. New Dehli: Penguin.

Jami, N. (2012). Interfaith Dialogue And Sirat-Unabi (PBUH). Paper presented at the International Seerat Conference, The Islamia University of Bahawalpur.

Joyner, N., \& Mengistus, B. (2012). Transforming Tolerance into Empathy: Cultural Imperatives in the Interfaith Dialogue. Paper Presented at the Global Awareness Society International 21st Annual Conference, New York.

Karim, K. M., Saili, S. A. \& Khambali, K. M. (2014). Role of Religious Leader in Interfaith Dialogue towards Conflict Resolution: An Islamic Perspective. International Journal of Education and Research, vol.2:6, pp.77-88.

Kefa, A. K. \& Moses, O. M. (2012). Mannual Inter-Religious Dialogue NairobiWestlands, Kenya: Franciscan Kolbe Press.

Khambali, K. M., Sintang, S., Senin, N. \& Shahrud-Din, S. (2013). Interfaith Dialogue in the Context of Comparative Religion. Middle-East Journal of Scientific Research, vol.14:12, pp.1599-1612.

Khan, M. W. (2015). Islam and Peace. India: Goodword.

Koreshi, S. M. (2001). New World Order: Western Fundamentalism in Action. Islamabad: Institute of Policy Studies. 
Krebs, S. R. (2014). Voices of Interfaith Dialogue: A Phenomenological Analysis. Colorado State University.

Kurucan, A., \& Erol, M. K. (2012). Dialogue in Islam. Quran-Sunnah-History. London: Dialogue Society.

Mahmood, M. R., \& Ghauri, I. u. R. (2013). Inter-Faith Dialogue in Pakistan: An Analysis of Historical Tradition and Contemporary Challenges. Al-Adwa, vol.47:32, pp.51-64.

Mehta, M. (2016). Promoting Peace through Interfaith Dialogue, Gulf News. Retrieved from: https:/gulfnews.com/lifestyle/promoting-peace-throughinterfaith-dialogue-1.1945015

Nadvi, S. S. (2012). Interfaith Dialogue in the Light of Sirah of The Prophet. Paper presented at the International Seerat Conference, The Islamia University of Bahawalpur.

Old, J. P. (2016). Interfaith Dialogue in a Complicated World. The Cresst (Lent), vol.79:3, p.5.

Ramzan, M. (2015). Sectarian landscape, Madrasas and Militancy in Punjab. Journal of Political Studies, vol.22:2, pp.421-436.

Rasul, A. (2009). The Role of Religion in Peace Making. Paper Presented at the CSID 10th Annual Conference, Sheraton Crystal City Hotel, USA.

Sahin, Z. (2009). Interfaith Dialogue Organizations as Actors of Peace Building: Case of Rumi Forum. Paper presented at the Conference titled "Islam in the Age of Global Challenges". Washington, DC.

Sanaullah, M. (2014). Interfaith Dialogue in Islam: A Scriptural Scrutiny. Journal of Humanities and Social Sciences, vol.19:3, pp.86-91.

Scheffler, T. (2007). Interreligious Dialogue and Peacebuilding. Die FriedensWarte, vol.82:2/3, pp.173-187.

The Express Tribune (3 August 2015). Number Crunching: Nearly half of Punjab's Seminaries are Unregistered, The Express Tribune. Retrieved from: https://ribune.com.pk/story/931249/number-crunching-nearly-halfof-punjabs-seminaries-are-unregistered/ 
UNDP. (2009). Why Dialogue Matters for Conflict Prevention and Peace Building. Democratic Republic of Congo.

Villumstad, S. (2002). Frameworks for Dialogue: Interfaith Action in Times of Conflict: Life \& Peace Institute.

Yusof, W. S. W. \& Ab Majid, A. (2012). Inter-Religious Dialogue Models in Malaysia. Global Journal Al Thaqafah, vol.2:1, pp.7-13.

Mansoor Ali Shah is Lecturer in the Department of Social Work, The Islamia University of Bahawalpur.

Dr. Asif Naveed Ranjha is an Assistant Professor in the Department of Social Work, The Islamia University of Bahawalpur. 